\title{
Antibiograms of Staphylococcus aureus and Pseudomonas aeruginosa which Colonize the Conjunctiva of HIV/AIDS Patients in Relation to their CD4 Counts
}

\author{
F. D. Otajevwo (Corresponding author) \\ Department of Microbiology \& Biotechnology, Western Delta University \\ Oghara, Nigeria \\ E-mail: dafinotaj@yahoo.com \\ B. O. Ajayi \\ Department of Optometry, Faculty of Life Sciences \\ University of Benin, Nigeria \\ E. Oghre \\ Department of Optometry, Faculty of Life Sciences \\ University of Benin, Nigeria
}

Received: July 20, 2011 Accepted: August 5, 2011 doi:10.5539/gjhs.v3n2p153

\begin{abstract}
One hundred (100) conjunctival swabs were collected from Enzyme-linked Immunosorbent Assay (ELISA)-confirmed HIV/AIDS seropositive patients who were referred to the HIV/AIDS laboratory of the University of Benin Teaching Hospital, Nigeria for routine CD4 count check. Swabs were bacteriologically processed and bacterial strains obtained from CD4 count groups were subjected to invitro antibiotic testing by disc diffusion technique in relation to their CD4 groups. Thirty four (34.0\%) patients had CD4 counts within group 1 ( $<500$ cells/ $\mu \mathrm{l}), 36(36.0 \%)$ in group 2 (200 cells/ $\mu \mathrm{l})$ and $30(30.0 \%)$ in group $3(>200$ cell/ $\mu \mathrm{l})$. While there was no bacterial growth after 48hrs incubation recorded for group 1, only 5(13.9\%) samples yielded growth of Staphylococcus aureus for group 2 with 31(86.1\%) yielding no bacterial growth. All group 3 samples yielded profuse growth of which 11(36.7\%) yielded Pseudomonas aeruginosa and 19(63.3\%) yielded Staph aureus. Staphylococcus. aureus strains isolated from the 19(63.3\%) group 3 samples showed invitro sensitivity reactions to ten antibiotics as follows: zinnat (57.9\%) pefloxacine (55.3\%), rocephine (51.3\%) and gentamycin (50.0\%). The others recorded less than 50\% sensitivity. Multiple resistance to 6(60\%) of antibiotics used was shown by 6(31.6\%) out of the 19 strains. The antibiogram of the 11(36.7\%) Pseudomonas aeruginosa strains showed ciprofloxacin (52.3\%) and gentamycin (50.0\%) reaction. The remaining eight recorded less than 50\% sensitivity of which, 4(36.4\%) P. aeruginosa strains showed multiple resistance to 50\% of antibiotics used. The 5(13.9\%) group 2 Staph. aureus strains showed invitro antibiotic susceptibility reactions as follows: pefloxacine (65.0\%), gentamycin (60.0\%), rocephine (55.0\%), ciprofloxacin (55.0\%) and streptomycin (50.0\%). Others recorded less than $50 \%$ reaction and none of the strains in this group recorded multiple resistances. Unpaired t-test analysis showed that whereas the differences in susceptibilities of both organisms to ofloxacine, pefloxacine, gentamycin, ampicillin, zinnat, rocephine, ciprofloxacin and sperfloxacin were insignificant $(\mathrm{P}>0.05)$, differences in susceptibilities to streptomycin was highly significant $(\mathrm{P}<0.01)$ and significant to augmentin $(\mathrm{P}<0.05)$.
\end{abstract}

Keywords: HIV, CD4 counts, Staph. aureus, P. aeruginosa, Colonize, Antibiograms

\section{Introduction}

The clinical manifestation of HIV secondary infections in developing countries including Nigeria shows a high prevalence of infections of the eyes, skin, among others (Akolo and Ukoli, 2005). The Human T-lymphotropic virus Type III (HTLV-III) has been found in tears thus indicating the presence of free virus in 
tears. Retroviral patients in their immune-compromised state would have a wider range of bacterial organisms present in their eyes. These organisms include Staphylococcus spp and Pseudomonas spp among others. Staphylococcus and Pseudomonas organisms are opportunistic pathogens in humans which can infect the eyes through contaminated fingers/contact lenses. Pseudomonas aeruginosa has emerged as one of the most common causes of gram negative bacteraemia with possible dissemination to the eyes (Adeleye et al., 2008; Hart et al., 2000).

The presence of bacteria in the eye could lead to bacterial retinitis, conjunctivitis, keratitis, neonatal ophthalmia, hordeolum (swelling of the eyelid due to infection of the glands), and blepharitis (Yasuyuki and Ben, 2005). The complete tear fluid (secreted by the lachrymal gland) contains antibacterial enzymes like lysozyme which can kill commonly occurring micro organisms like Staphylococci and Streptococci. The tear film is the natural eye defense mechanism and is made up of mucin layer, aqueous layer and lipid layer. The aqueous layer contains antimicrobial factors such as lactoferin, lysozyme, IgA and proteins such as beta lysins. All these help to protect the eye and the ocular surface.

The ocular surface is constantly exposed to a wide array of microorganisms and therefore, a combination of mechanical, anatomical and immunological defense mechanisms have evolved to protect the outer eye (Akpek and Gottsch, 2003). These defense mechanisms are usually overwhelmed in immune-compromised individuals (such as HIV/AIDS patients), individuals on corticosteroid therapy, adverse environmental changes and in debilitating disease conditions such as diabetes mellitus (Chiegbu et al., 2003). An outcome of an immune-compromised HIV seropositive patient is direct effect on T-lymphocytes called CD4 cells.

The CD4 cells (also known as T-cells) are an important part of the immune system. People with AIDS (full blown) have fewer CD4 cells compared to seronegative healthy individuals (Adeleye et al., 2010). Different people with AIDS may possess different values of CD4 cells. Those with higher CD4 counts usually feel better and are less likely to go down with opportunistic infections. Hence, a CD4 count assay is used to monitor the effectiveness of a course of treatment. If a particular anti-retroviral drug (medication) raises the level of CD4 count (from what it was before treatment), it means by interpretation, that the drug is working. Normal adult CD4 count reference varies between $500-1500$ cell $/ \mathrm{mm}^{3}$ whole blood with approximately $400-1200 / \mathrm{mm}^{3}$ for men and $500-160 / \mathrm{mm}^{3}$ for women (CDC, 1993).

In addition, the CD4 T-cell values fluctuate with the time the assay is done. Fatigue and stress may also influence CD4 count (Ebona et al., 2007). It is recommended that all patients' blood samples should be collected at the same daytime for each CD4 test and the same laboratory should be used to analyze all samples (Giorgis et al., 2007). Other factors that can affect (increase) CD4 counts are infections (which naturally will increase white cell and lymphocyte counts), seasonal and diurnal variation, surgery, viral infections, tuberculosis and splenectomy (Giorgis et al., 2007). Factors that can decrease CD4 counts are corticosteroid therapy, cancer therapy etc. Sex, race, psychological stress and physical stress have minimal effect on CD4 count. Prescott (1990), in a study, stated that Staphylococcus aureus, Streptococcus pneumoniae and Pseudomonas aeruginosa were found to adhere to corneal epithelium significantly better than other species that were tested for adhesion to corneal epithelium. This result suggested that the frequency with which certain bacteria cause corneal ulceration may be related to the ability of those organisms to adhere to corneal epithelium.

Moss et al. (2002) in a related study, associated Staphylococcus aureus colonization of nasal epithelium with CD4 T-cell count among HIV seropositive patients in a poor urban community $((\mathrm{P}<0.05)$. According to their report, Staph. aureus colonization rate among HIV positive individuals increased as CD4 count decreased. Patients with CD4 counts below 200 had greater rates of nasal colonization than those with higher CD4 counts. It is expected as reported by Moss et al. (2002) that there will be stronger nasal colonization of bacteria particularly Staph. aureus. This stronger adhesion may lead to difficulties in antibiotic treatment of nasal infections due to these bacterial organisms.

According to Yasuyuki and Ben. (2005). Staph. aureus and P. aeruginosa are constantly linked with corneal infections in HIV patients. Practitioners may encounter difficulty in treating such infections owing to various immune-compromised stages HIV patients may be. This may or may not have direct relationship with viral load as against CD4 count. The aim of this work therefore, is to investigate the antibiograms of Staphylococcus aureus and Pseudomonas aeruginosa which colonize the conjunctiva of HIV/AIDS patients in relation to their CD4 counts with the following objectives: 1. Isolate Staph. aureus and Pseudomonas aeruginosa from the conjunctiva of HIV/AIDS seropositive patients taking note of their CD4 T-cell counts, 2. Establish antibiotic susceptibilities of these bacteria so as to determine if the susceptibility is due to their occurrence in relation to the CD4 counts of the 
patients from whose eyes they are isolated. The idea is to facilitate the treatment of HIV/AIDS patients presenting with any eye disease using their CD4 counts as a guide.

\section{Materials and methods}

With informed consent and approval obtained from the ethical committee of the hospital management, 100 eye (conjunctival) swabs were collected from Enzyme-linked Immunosorbent Assay (ELISA) - confirmed HIV/AIDS seropositive patients who were referred to the HIV/AIDS laboratory of the University of Benin Teaching Hospital, Nigeria for routine CD4 count check (to monitor the progress of the disease and response to anti - retroviral therapy). Samples were collected between January to March, 2009.

Swabs were neatly collected (by retracting the lids carefully and swabbing through with sterile swab sticks) after blood samples had been withdrawn for CD4 T-cell counts by laboratory personnel. Patients' full data were noted (with proper labeling) in order to match culture results with CD4 counts.CD4 count results were collated and grouped into groups 1-3 according to Centre for Disease Control and Prevention ${ }^{9}$ scheme. The swab samples were coded 1-100 with names of patients written by each code. Only CD4 counts reported within 3months (period of sample collection) were collated and used.

Swabs were cultured aseptically on sterile MacConkey, Blood and Mannitol salt agar plates and incubated at $37^{\circ} \mathrm{C}$ for 24hours. Pure (axenic) isolates/strains were obtained and stocked on sterile nutrient agar slants. Gram staining was also done and results recorded.

Pure isolates were identified culturally, morphologically, biochemically and by sugar fermentation according to schemes provided by Cowan and Steel (1993) and Cullimoore (2000). All catalase positive, coagulase positive colonies, gram positive cocci in clusters, glucose positive, mannitol positive (characteristic of Staphylococcus aureus) and all citrate positive, oxidase positive colonies (with gray-greenish pigmentation), short gram negative rods in singles (characteristic of Pseudomonas aeruginosa) were stocked on sterile agar slants for further use. Stocked pure cultures (strains) were then subjected to invitro antibiotic testing.

\subsection{Invitro antibiotic testing}

This was done according to the modified disc diffusion technique of Bauer et al. (1997). Sterile nutrient agar plates and peptone water prepared and dispensed into bijou bottles were prepared in accordance with manufacturer's instructions. An inoculum of the stock culture of each strain was subcultured into sterile peptone water (in bijou bottles) and incubated on the bench for 2-3hours. A sterile peptone water bottle (which was not subcultured) was used as control. All steps were carried out with proper labeling.

Sterile nutrient agar plates were arranged and labeled for the strains of each isolate with one reserved as control. The plates were flooded with the liquid culture in the bijou bottles and the control bijou bottle was equally used to flood the control plate. The excess liquid culture was drained off the plates. Using well sterilized pair of forceps, commercially obtained gram positive and gram negative multidrug discs were impregnated on the flooded agar surface. While gram positive discs were used for Staph aureus strains, gram negative discs were used for Pseudomonas aeruginosa. The control plate was divided into two halves. On one half, gram positive discs were impregnated and gram negative discs on the other.

All plates were then incubated aerobically at $37^{\circ} \mathrm{C}$ for 24 hours. Results were interpreted according to the National Committee for Clinical Laboratory Standards.

\section{Results}

Out of the 100 blood samples assayed for CD4 counts, 34 (34.0\%) had their counts within group 1 (>500 cells/ $\mu$ l) range, 36 (36.0\%) within group 2 (200-499 cells/ $\mu$ l) range and 30 (30.0\%) in the group $3(<200$ cells/ $\mu \mathrm{l})$ range (Table 1).

Bacteriological (cultural) results showed that all samples/patients in CD4 count group 1 yielded no bacterial growth after incubation. In the case of CD4 count group 2, whereas only five samples yielded growth of Staphylococcus aureus, the others did not yield any bacterial growth. All samples placed into group 3 yielded profuse growth of which 11(11.0\%) yielded Pseudomonas aeruginosa while 19(19.0\%) yielded Staph. aureus. On the whole, whereas 11 (11.0\%) samples yielded profuse growth of Pseudomonas aeruginosa, 24 (24.0\%) yielded Staph. aureus (Table 2).

Staph. aureus strains isolated from 19 group 3 samples (Table 2) were subjected (sensitivity testing) invitro to ten different antibiotics which included pefloxacine, gentamycin, ampiclox, zinnat (cefuroxime), ampicillin, rocephine (ceftriaxone), streptomycin, ciprofloxacin, septrin (clotrimoxazole) and erythromycin. The overall sensitivity pattern showed zinnat (57.9\%), pefloxacine (55.30\%), rocephine (51.3\%), and gentamycin (50.0\%) in 
that decreasing order of sensitivity. The others which recorded less than $50 \%$ sensitivity were ciprofloxacin (47.4\%), streptomycin (43.4\%), septrin (26.4\%), ampicillin (22.4\%), erythromycin (22.4\%) and ampiclox (7.9\%). Of the 19 strains of Staph. aureus, 6 (31.6\%) showed multiple resistance to 6(60\%) of antibiotics used (Table 3).

Eleven samples which recorded CD4 count of $>200$ cells/ $\mu$ l yielded 11 Pseudomonas aeruginosa strains. Their invitro antibiotic sensitivity results showed ciprofloxacin (52.3\%) and gentamycin (50.0\%) in that decreasing order. Susceptibilities of less than 50\% were recorded for pefloxacin (49.5\%), ofloxacine (43.2\%), ampicillin (34.1\%), streptomycin (29.6\%), sperfloxacine (29.6\%), septrin (27.3\%), chloramphenicol (25.0\%) and augmentin (22.7\%) in that decreasing order (Table 4). Of the 11 strains, 4 (36.4\%) showed multiple resistance to 6(60\%) of antibiotics used.

Five samples from five patients who recorded 200-499 cells/ $\mu \mathrm{l} \mathrm{CD4} \mathrm{count} \mathrm{yielded} \mathrm{five} \mathrm{strains} \mathrm{of} \mathrm{Staph.} \mathrm{aureus} \mathrm{to}$ which the drugs used in Table 1 were subjected. Their invitro sensitivity reactions were pefloxacine (65.0\%), gentamycin (60.0\%) rocephine (55.0\%), ciprofloxacin (55.0\%) and streptomycin (50.0\%) in that decreasing order (Table 5). Sensitivities of less than 50\% were recorded for zinnat (45.0\%) septrin (35.0\%), erythromycin (35.0\%), ampicillin (30.0\%) and ampiclox (25.0\%) in that descending order (Table 5). There was no record of multiple resistance against drugs used for any of the strains.

The differences in susceptibilities between Staph. aureus and Pseudomonas aeruginosa to each of the antibiotics applied to both organisms were statistically analyzed using an unpaired t-test. As shown in Table 6, whereas the differences in susceptibilities of both organisms to ofloxacine, pefloxacine, gentamycin ampicillin, zinnat, rocephine, ciprofloxacin and sperfloxacine were insignificant $(\mathrm{P}>0.05)$, differences in susceptibilities to streptomycin was highly significant $(\mathrm{P}<0.01)$ and significant to augmentin $(\mathrm{P}<0.05)$.

\section{Discussion}

All patients used for the study were confirmed by Enzyme linked Immunosorbent Assay (ELISA) to be HIV seropositive. Patients may have been at various stages of advancement or progression of the disease. This may explain why $34(34.0 \%)$ of them recorded a CD4 count greater than 500 cells/ $\mu \mathrm{l}$ (Table 1). It may be that this group of patients recently got infected or recently became seropositive. The highest number of patients (36) and representing $36.0 \%$ of sampled population fell into the bracket of 200-499cells/ $\mu$ l or group 2 (Table 1). Here, CD4 counts have begun to drop suggesting progression of disease in terms of replication of the retrovirus inside $\mathrm{T}$ cells with their eventual damage and depletion. Patients in group 3 which represented 30\% of samples recorded sharp drop in CD4 counts. There is likely to be further progression of disease giving room to opportunistic infections including bacterial infection (Ebana et al., 2007).

According to CDC (1993), different people with AIDS possess varying values of CD4 T-cells and those with higher CD4 counts usually feel better and are less likely to go down with opportunistic infections. Biswas et al. (2000) reported that the pattern of ocular manifestations in HIV/AIDS patients observed in different studies seem to suggest that it is related to the CD4 counts. Related to this, is the finding of Copeland (2005) which stated that some sight threatening eye diseases in AIDS patients occur at late stage in the disease when the immunity has been severely compromised and with a CD4 count less than $100 / \mathrm{mm}^{3}$.

The growth and isolation of 11 strains of Pseudomonas aeruginosa and 19 strains of Staphylococcus aureus from all 30 (30.0\%) samples of group 3 somewhat confirms the extent of immuno compromised condition of this group of patients. Group 1 samples did not yield any bacterial growth and this is probably due to their intact state of health (though recently infected probably as evidenced by a CD4 count equal to or greater than 500 )Table 2 . Hence, HIV seropositive patients with CD4 counts below 200 have far greater rates of Pseudomonas aeruginosa and Staphylococcus aureus colonization compared to those with higher CD4 counts and this tends to agree with the report of Moss et al. (2002) which stated that bacterial colonization increases with decreasing CD4 counts. Findings in this study are also supported by Adeleye et al. (2010), Farrokh et al. (2008) and Goose (1998) who reported that due to the weakened defense (immune) systems of HIV/AIDS victims, they become hosts especially to opportunistic pathogens.

Staphylococcus aureus strains isolated from 19 patients who recorded CD4 T-cell counts of less than 200 showed varying susceptibility patterns (antibiograms) to pefloxacine, gentamycin, ampiclox, zinnat, ampicillin, septrin, rocephine, streptomycin, ciprofloxacin and erythromycin invitro (Table 3). This sensitivity pattern differed from that obtained by Shittu and Lin (2006). In decreasing order of sensitivity, the strains were most sensitive to zinnat (57.9\%), pefloxacine (55.3\%), rocephine (51.3\%) and gentamycin (50.0\%). Unfortunately, the first three (which are broad spectrum antibiotics) are expensive and unaffordable to majority of victims due to their low socio-economic status or low income. 
Ciprofloxacin, streptomycin, septrin, erythromycin, and ampicillin recorded less than $50 \%$ sensitivity in that decreasing order suggesting their unsuitability for treatment of bacterial infections of the eye of HIV/AIDS victims having CD4 counts less than 200. Apart from ciprofloxacin, the others are relatively cheap and affordable. Their low sensitivity may be as a result of resistance due to constant indiscriminate use and abuse of the drugs. According to Rawstron (1999), bacteria that used to be curable with antibiotics are now resistant. A combination of gentamycin and ampicillin or gentamycin and ampiclox however, will produce synergistic effect (Ochei and Kolhatkar, 2008).

The antibiogram of Pseudomonas aeruginosa strains isolated from the eyes of patients having CD4 count of less than 200 (Table 4) was a little different. The strains were sensitive to ciprofloxacin (52.3\%) and gentamycin (50.0\%) in that order. Those that were less than 50.0\% susceptible included pefloxacin (49.5\%), ofloxacine (43.2\%), ampicillin (34.1\%), streptomycin (29.6\%), sperfloxacine (29.6\%), septrin (27.3\%), chloramphenicol (25.0\%) and augmentin (22.7\%) (Table 4). Again, apart from gentamycin, the others like ciprofloxacin and pefloxacine are expensive and maybe unaffordable. However combinations of gentamycin and other antibiotics having less than $50 \%$ susceptibility may produce synergistic response to most stubborn eye bacterial diseases caused by Pseudomonas aeruginosa (Manfredi et al., 2000). The high degree of sensitivity of Pseudomonas aeruginosa strains to ciprofloxacine is supported by Manfredi et al. (2000) who reported $100 \%$ susceptibility to ciprofloxacine.

Pefloxacine (65.0\%), gentamycin (60.0\%), rocephine (55.0\%), ciprofloxacin (55.0\%) and streptomycin (50.0\%) in that order was the antibiotic sensitivity pattern of Staphylococcus aureus strains isolated from patients whose CD4 counts ranged from 200-499 cells/ $\mu \mathrm{l}$ (Table 5). This result suggests pefloxacine as the drug of choice for this category of patients. Again, apart from gentamycin and streptomycin, the others are expensive particularly when a prolonged dose is prescribed to tackle a chronic eye disease. Hence, gentamycin can still be used as an affordable and effective alternative.

The unpaired t-test statistical analysis of susceptibility differs between Staph. aureus and Pseudomonas aeruginosa to each of the antibiotics applied to both organisms showed that whereas the differences in susceptibilities of both organisms to ofloxacin, pefloxacin, gentamycin, ampicillin, zinnat, rocephin, ciprofloxacin and sperfloxacine were insignificant $(\mathrm{P}>0.05)$, differences in susceptibilities to streptomycin was highly significant $(\mathrm{P}<0.01)$ and significant to augmentin $(\mathrm{P}<0.05)$ Table 6 . The import of this is that any of ofloxacin, pefloxacin, gentamycin, ampicillin, zinnat, rocephine, ciprofloxacin or sperfloxacine can be used to treat any ocular infections caused by either Staph. aureus or Pseudomonas aeruginosa depending on their degree of sensitivity, cheapness and availability. However streptomycin $(1.89 \pm 0.06)$ will be much more effective in curing eye (conjunctival) infections due to Staph. aureus than that due to Pseudomonas aeruginosa $(\mathrm{P}<0.01)$. Similarly, augmentin $(1.83 \pm 0.17)$ followed the same trend $(\mathrm{P}<0.05)$.

\section{Conclusion}

The results of this study suggest pefloxacine as drug of choice for treatment of eye co-infections by Staph. aureus suffered by HIV/AIDS patients having CD4 counts of 200 - 499 cells/ $\mu l$. In terms of affordability, gentamycin can be used as an effective alternative. Results also proffer cefuroxme (zinnat) or ciprofloxacin as drug of choice for treating eye disease suffered by HIV/AIDS patients having CD4 counts of less than 200 cells/ $\mu \mathrm{l}$ with gentamycin as a standby potent alternative.

Based on statistical comparison of susceptibility differences between Staphylococcus aureus and Pseudomonas aeruginosa to each antibiotic applied to both organisms, any of ofloxacin, pefloxacin, gentamycin, ampicillin, rocephine, or sperfloxacin can be used to treat any ocular infections caused by Staphylococcus aureus or Pseudomonas aeruginosa depending on their degree of sensitivity, cheapness and availability.

Combinations of gentamycin and any other antibiotics having less than 50\% susceptibility may produce synergistic effect on stubborn eye bacterial diseases caused by any of the two pathogens. The combination of gentamycin with any of the less sensitive antibiotics in small and non-toxic concentrations is recommended for application in the manufacture of eye drop solutions. The sustained use of gentamycin eye drops without any form of adulteration should be encouraged 


\section{References}

Adeleye, I. A., Akanmu, A. S., Bamiro, B. S., Obosi, A. C., \& Inem, A. V. (2010). Bacterial bloodstream Infections in HIV-infected adults attending a Lagos Teaching Hospital. Journ Health Popul Nutr, 28 (4), $318-326$.

Adeleye, I. A., Akanmu, A. S., Bamiro, B. S., Obosi, A. C., Smith, S., Inem, A. V., \& Sobande, O. (2008). Chromosomally mediated antibiotic resistance in non-typhoidal Salmonellae isolates from HIV patients in Lagos. West Ind Med Journ, 57, 548-549.

Akolo, C. U. \& Ukoli, I. J. (2005). Abstracts book of the $14^{\text {th }}$ International Conference on AIDS and STDs in Africa. Spectrum of Clinical diseases at presentation in 200 HIV/AIDS patients at the Jos University Teaching Hospital, Nigeria.

Akpek, E. K. \& Gottsch, J. D. (2003). Immune defense at the ocular surface. Ophthalmology, 17, 949-956.

Bauer, A. W., Kirby, W. M., \& Sheris, J. C. (1997). Antibiotic Antibiotic testing by a standardized disk method. Amer J. Clin Path, 45, 493-496.

Biswas, J., Madhavan, H. N., \& George, A. E. (2000). Ocular lesions associated with HIV infection in India, a series of 100 consecutive patients evaluated at a referral center. Am. J. Opthalmol, 129, 9-15. http://dx.doi.org/10.1016/S0002-9394 (99)00415-8

Centre for Disease Control. (1993). Revised classification System for HIV Infection and Expanded surveillance. Case definition for AIDS among adolescent adults. MMWR, 41, 19-22.

Chiegbu, D., Isiwu, J., \& Dowo, L. (2003). Bacterial infections and treatment for patients. Arch Ophthamol, 102, 201-206.

Copeland, R. (2005). Review of ocular manifestations of HIV. Ophthalmology, 114(12), 1453-9 .

Cowan, S. T. \& Steel, K. J. (1993). Manual for the identification of medical bacteria. Cambridge University Press, London, New York, Rockville, Melbourne and Sydney. 411p.

Cullimoore, D. R. (2000). Practical Atlas for Bacterial Identification. Lewis Publishers, Boca Raton, London, New York. 209p.

Ebana Mvogo, C., Ellong, A., Bella, A. C., Lumah, A., \& Chu, Jokoh. (2007). Ocular complications of HIV/AIDS in Cameroon, Is there is any correlation with the level of CD4 Lymphocyte. Bull. Soc. Belge. Opthalmo, 305, 7-12.

Farrokh, S. (2008). Molecular Koch’s postulate applied to microbial pathogenicity. Rev Infect Dis Suppl, 3, 274-277.

Fujikawa, L. S., Salahudin, S. H., Ablashi, D., Palestine, A. G., \& Masur, H. (1985). Isolation of human T. Lymphotropic Virus type III from tears of an AIDS patient. A M Journ Ophthalmol, 100, 507-509.

Giorgis, A., Melka, F. G., \& Morion, A. (2007). Opthalmic manifestations of AIDS in Armed Forces General Teaching Hospital, Addis Ababa. Ethiop. Med. J., 45 (4), 327-334.

Goose, L. (1998). HIV in-site knowledge. Base chapter. MD Standford University Press. 50p.

Hart, C. A., Beeching, N. J., \& Duerden, B. I. (2000). Infections in AIDS. Journ. Med. Microbiol, 49, $947-967$.

Manfred, R., Nanetti, A., Ferri, M., \& Chiodo, F. (2000). Pseudomonas spp. Complications in patients with HIV disease. An eight Year Clinical and Microbiological Survey. European J. Epidemiol, 16, 111-118.

Moss, C. E., Andrew, P., \& Arnold, R. (2002). Gram negative bacterial in children. J. Infect. Dis, 120, $180-186$. http://dx.doi.org/10.1023/A,1007626410724

National Committee for Clinical Laboratory Standards. (1997). Methods for Dilution Antimicrobial Susceptibility Test for bacteria that grow aerobically. $4^{\text {th }}$ edn. Approved standard M7-A4. NCCLS, Vilanova, P. A.

Ochei, J. \& Kolhatkar, A. (2008). Medical Laboratory Science, Theory and Practice. $10^{\text {th }}$ edn. Tata McGraw-Hill Publishing Company Limited, New Delhi. 1338p.

Prescott, C. (1990). Bacterial infections in children with HIV/AIDS. Tropic Doctor, 34, 195-198.

Rawstron, S. Supergerms. Bacteria that Antibiotics cannot kill! PWA Health Group, 1 (1), Spring-Summer 1999. The body. [Online] Available: http://www.thebody.com/content/art4787.html

Shittu, A. O. \& Lin, J. (2006). Antimicrobial Susceptibility patterns and characterization of clinical isolates of Staphylococcus aureus in KwaZulu- Natal province, South Africa. BMC Infect. Dis, 6, $125-128$. http://dx.doi.org/10.1186/1471-2334-6-125

Yasuyuki, T. \& Ben, J. (2005). Conjunctival flora of HIV patients. Journ. Infect. Dis, 120, 180-186. 
Table 1. Distribution of patients/samples into CD4 Groups

\begin{tabular}{|c|c|c|}
\hline Swab Sample Codes & Total (\%) & CD4 Group (CDC, 1997) \\
\hline $\begin{array}{l}3,6,10,11,12,13,15 \\
17,20,21,25,31,32, \\
34,38,40,42,44,45 \\
46,50,51,52,53,54,56, \\
57,58,59,60,61,62, \\
63,64\end{array}$ & $34(34.0 \%)$ & Group $1>500$ cells/ $\mu \mathrm{l}$ \\
\hline $\begin{array}{l}65,66,67,68,69,70,71,72, \\
73,74,75,76,77,78,79,80, \\
81,82,83,84,85,86,87,88, \\
89,90,91,92,93,94,95,96, \\
97,98,99,100\end{array}$ & $36(36.0 \%)$ & $\begin{array}{l}\text { Group } 2 \\
200 \text { - } 499 \text { cells/ } \mu l\end{array}$ \\
\hline $\begin{array}{l}\text { 1,2,4,5,7,8,9,14,16,18, } \\
\text { 19,22,23,24,26,27,28, } \\
29,30,33,35,36,37,39,41, \\
43,47,48,49,55\end{array}$ & $30(30.0 \%)$ & $\begin{array}{l}\text { Group } 3 \\
<200 \text { cells/ } \mu \mathrm{l}\end{array}$ \\
\hline
\end{tabular}

Table 2. Bacterial Colonization of the Conjunctiva in Relation to CD4 counts

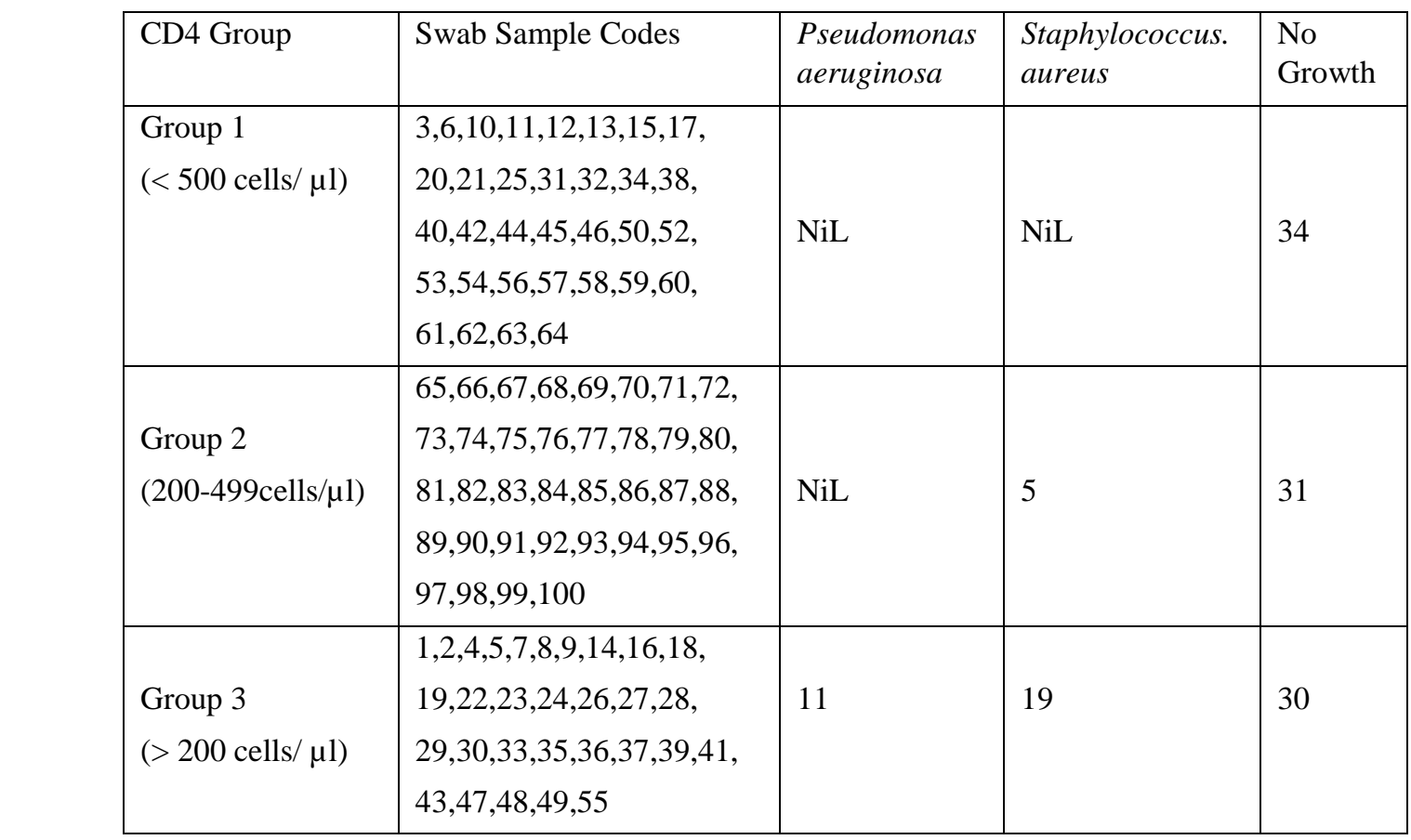

Note:

Group 2 swab codes that yielded Staph.aureus: 69, 71, 85 and 100

Group 3 swab codes that yielded Staph aureus: 7,9,14,16,18,19,22,23,24,26,27,28,31,36,37,41,43,49,55

Group 3 swab codes that yielded Pseud. aeruginosa: 2,5,7,16,19,22,24,28,30,33,55 
Table 3. Antibiogram of Staphylococcus aureus strains isolated from patients with <200cells/ $\mu$ l) CD4 T-cell counts

\begin{tabular}{|c|c|c|c|c|c|c|c|c|c|c|}
\hline $\begin{array}{c}\text { Swab } \\
\text { Sample } \\
\text { code Nos }\end{array}$ & $\begin{array}{c}\text { PEF } \\
(\%)\end{array}$ & $\begin{array}{c}\text { ANGN } \\
(\%)\end{array}$ & $\begin{array}{c}\text { TIBAPX } \\
(\%)\end{array}$ & $\begin{array}{c}\text { IOTICZ } \\
(\%)\end{array}$ & $\begin{array}{c}\text { SAM } \\
(\%)\end{array}$ & $\begin{array}{c}\text { USERO } \\
(\%)\end{array}$ & $\begin{array}{c}\text { DST } \\
(\%)\end{array}$ & $\begin{array}{c}\text { CPX } \\
(\%)\end{array}$ & $\begin{array}{c}\text { SEP } \\
(\%)\end{array}$ & $\begin{array}{c}\text { E } \\
(\%)\end{array}$ \\
\hline 22 & 25.0 & 25.0 & 25.0 & 50.0 & 25.0 & 25.0 & 25.0 & 50.0 & 25.0 & 25.0 \\
\hline 23 & 50.0 & 50.0 & $\mathrm{R}$ & 25.0 & 25.0 & 25.0 & 25.0 & 50.0 & $\mathrm{R}$ & 25.0 \\
\hline 24 & 50.0 & 50.0 & $\mathrm{R}$ & 50.0 & 25.0 & 50.0 & 50.0 & 50.0 & 50.0 & 25.0 \\
\hline 26 & 75.0 & 50.0 & $\mathrm{R}$ & 50.0 & 25.0 & 50.0 & 25.0 & 50.0 & 25.0 & 25.0 \\
\hline 27 & 75.0 & 50.0 & 25.0 & 50.0 & 25.0 & 50.0 & 25.0 & 25.0 & 25.0 & 25.0 \\
\hline 28 & $\mathrm{R}$ & 25.0 & $\mathrm{R}$ & 25.0 & $\mathrm{R}$ & 25.0 & 25.0 & $\mathrm{R}$ & 25.0 & $\mathrm{R}$ \\
\hline 29 & 25.0 & 25.0 & $\mathrm{R}$ & 50.0 & $\mathrm{R}$ & 50.0 & 50.0 & 50.0 & 25.0 & 25.0 \\
\hline 30 & 75.0 & 50.0 & 25.0 & 75.0 & 50.0 & 75.0 & 25.0 & 50.0 & 25.0 & 25.0 \\
\hline 33 & 75.0 & 50.0 & $\mathrm{R}$ & 75.0 & $\mathrm{R}$ & 50.0 & 25.0 & 25.0 & 25.0 & $\mathrm{R}$ \\
\hline 35 & 75.0 & 75.0 & $\mathrm{R}$ & 50.0 & $\mathrm{R}$ & 75.0 & 50.0 & 75.0 & $\mathrm{R}$ & $\mathrm{R}$ \\
\hline 36 & 75.0 & 50.0 & $\mathrm{R}$ & 50.0 & $\mathrm{R}$ & 50.0 & 50.0 & 50.0 & 25.0 & 25.0 \\
\hline 37 & 50.0 & 50.0 & 50.0 & 75.0 & 50.0 & 75.0 & 75.0 & 75.0 & 75.0 & 75.0 \\
\hline 39 & 75.0 & 75.0 & $\mathrm{R}$ & 75.0 & $\mathrm{R}$ & 50.0 & 50.0 & 75.0 & 50.0 & 50.0 \\
\hline 41 & 75.0 & 50.0 & $\mathrm{R}$ & 75.0 & 50.0 & 75.0 & 50.0 & 50.0 & $\mathrm{R}$ & $\mathrm{R}$ \\
\hline 43 & 75.0 & 25.0 & 25.0 & 50.0 & 25.0 & 50.0 & 25.0 & 25.0 & 25.0 & 25.0 \\
\hline 47 & 50.0 & 25.0 & $\mathrm{R}$ & 75.0 & 50.0 & 50.0 & 75.0 & 50.0 & $\mathrm{R}$ & 25.0 \\
\hline 48 & 50.0 & 75.0 & $\mathrm{R}$ & 75.0 & 50.0 & 50.0 & 50.0 & 50.0 & $\mathrm{R}$ & $\mathrm{R}$ \\
\hline 49 & $\mathrm{R}$ & 75.0 & $\mathrm{R}$ & 75.0 & $\mathrm{R}$ & 50.0 & 50.0 & 75.0 & 50.0 & 25.0 \\
\hline 55 & 75.0 & 75.0 & $\mathrm{R}$ & 50.0 & 25.0 & 50.0 & 50.0 & 25.0 & 25.0 & 25.0 \\
\hline Total 19 & $\mathbf{1 0 5 0}$ & $\mathbf{9 5 0 . 0}$ & $\mathbf{1 5 0 . 0}$ & $\mathbf{1 1 0 0}$ & $\mathbf{4 2 5 . 0}$ & $\mathbf{9 7 5 . 0}$ & $\mathbf{8 2 5}$ & $\mathbf{9 0 0 . 0}$ & $\mathbf{4 7 5 . 0}$ & $\mathbf{4 2 5 . 0}$ \\
\hline Average & $\mathbf{5 5 . 3 \%}$ & $\mathbf{5 0 . 0 \%}$ & $\mathbf{7 . 9 \%}$ & $\mathbf{5 7 . 9 \%}$ & $\mathbf{2 2 . 4 \%}$ & $\mathbf{5 1 . 3 \%}$ & $\mathbf{4 3 . 4 \%}$ & $\mathbf{4 7 . 4 \%}$ & $\mathbf{2 6 . 4 \%}$ & $\mathbf{2 2 . 4 \%}$ \\
\hline
\end{tabular}

PEF=Pefloxacine, GN=Gentamycin, APX=Ampiclox, Z=Zinnat, AM=Ampicillin, RO=Rocephin,

$\mathrm{ST}=$ Streptomycin, $\mathrm{CPX}=$ Ciprofloxacin, $\mathrm{SEP}=$ Septrin, $\mathrm{E}=$ Erythromycin

Table 4. Antibiogram of Pseudomonas aeruginosa strains isolated from patients having < 200 (cells/ $\mu \mathrm{l}$ ) CD4 counts

\begin{tabular}{|c|c|c|c|c|c|c|c|c|c|c|}
\hline $\begin{array}{c}\text { Swab } \\
\text { Sample } \\
\text { codes }\end{array}$ & $\begin{array}{c}\text { OFX } \\
(\%)\end{array}$ & $\begin{array}{c}\text { PEF } \\
(\%)\end{array}$ & $\begin{array}{c}\text { GN } \\
(\%)\end{array}$ & $\begin{array}{c}\text { AMP } \\
(\%)\end{array}$ & $\begin{array}{c}\text { CPX } \\
(\%)\end{array}$ & $\begin{array}{c}\text { ST } \\
(\%)\end{array}$ & $\begin{array}{c}\text { SEP } \\
(\%)\end{array}$ & $\begin{array}{c}\text { CHL } \\
(\%)\end{array}$ & $\begin{array}{c}\text { SP } \\
(\%)\end{array}$ & $\begin{array}{c}\text { AU } \\
(\%)\end{array}$ \\
\hline 1 & 25.0 & $\mathrm{R}$ & $\mathrm{R}$ & 25.0 & 50.0 & $\mathrm{R}$ & $\mathrm{R}$ & $\mathrm{R}$ & 25.0 & $\mathrm{R}$ \\
\hline 2 & 75.0 & 75.0 & 50.0 & 50.0 & 75.0 & 75.0 & $\mathrm{R}$ & 25.0 & 50.0 & 25.0 \\
\hline 4 & 25.0 & 50.0 & 75.0 & 25.0 & 25.0 & $\mathrm{R}$ & 25.0 & $\mathrm{R}$ & $\mathrm{R}$ & 25.0 \\
\hline 5 & 50.0 & 50.0 & 50.0 & 50.0 & 50.0 & 25.0 & 25.0 & 25.0 & 25.0 & 25.0 \\
\hline 7 & 75.0 & 75.0 & 75.0 & 50.0 & 50.0 & 50.0 & 50.0 & 50.0 & 50.0 & 50.0 \\
\hline 8 & 50.0 & 50.0 & 50.0 & 25.0 & 50.0 & 25.0 & 25.0 & 25.0 & 25.0 & $\mathrm{R}$ \\
\hline 9 & 50.0 & 50.0 & 50.0 & 25.0 & 50.0 & 50.0 & 50.0 & 25.0 & 25.0 & $\mathrm{R}$ \\
\hline 14 & 25.0 & 25.0 & 50.0 & $\mathrm{R}$ & 50.0 & $\mathrm{R}$ & 25.0 & 25.0 & 25.0 & $\mathrm{R}$ \\
\hline 16 & $\mathrm{R}$ & 70.0 & 25.0 & 25.0 & 50.0 & $\mathrm{R}$ & $\mathrm{R}$ & $\mathrm{R}$ & $\mathrm{R}$ & 25.0 \\
\hline 18 & 50.0 & 50.0 & 75.0 & 50.0 & 75.0 & 50.0 & 50.0 & 50.0 & 50.0 & 50.0 \\
\hline 19 & 50.0 & 50.0 & 50.0 & 50.0 & 50.0 & 50.0 & 50.0 & 50.0 & 50.0 & 50.0 \\
\hline Total $\mathbf{1 1}$ & $\mathbf{4 7 5 . 0}$ & $\mathbf{5 5 0 . 0}$ & $\mathbf{5 5 0 . 0}$ & $\mathbf{3 7 5 . 0}$ & $\mathbf{5 7 5 . 0}$ & $\mathbf{3 2 5 . 0}$ & $\mathbf{3 0 0 . 0}$ & $\mathbf{2 7 5}$ & $\mathbf{3 2 5 . 0}$ & $\mathbf{2 5 0 . 0}$ \\
\hline Average & $\mathbf{4 3 . 2 \%}$ & $\mathbf{4 9 . 5 \%}$ & $\mathbf{5 0 . 0} \%$ & $\mathbf{3 4 . 1 \%}$ & $\mathbf{5 2 . 3 \%}$ & $\mathbf{2 9 . 6 \%}$ & $\mathbf{2 7 . 3 \%}$ & $\mathbf{2 5 . 0 \%}$ & $\mathbf{2 9 . 6 \%}$ & $\mathbf{2 2 . 7 \%}$ \\
\hline
\end{tabular}

$\mathrm{PEF}=$ Pefloxacine, $\mathrm{GN}=$ Gentamycin, $\mathrm{AM}=$ Ampicillin, OFX=Ofloxacin, $\mathrm{ST}=$ Streptomycin, CPX=Ciprofloxacin, $\mathrm{SEP}=$ Septrin, $\mathrm{CHL}=$ Chloramphenicol, $\mathrm{SP}=$ Sperfloxacin, $\mathrm{AU}=$ Augmentin 
Table 5. Antibiogram of Staph. aureus strains isolated from patients having 200-499 cells/ $\mu$ l CD4 T-cell counts

\begin{tabular}{|c|c|c|c|c|c|c|c|c|c|c|}
\hline $\begin{array}{c}\text { Swab } \\
\text { code }\end{array}$ & $\begin{array}{c}\text { PEF } \\
(\%)\end{array}$ & $\begin{array}{c}\text { GN } \\
(\%)\end{array}$ & $\begin{array}{c}\text { APX } \\
(\%)\end{array}$ & $\begin{array}{c}\text { Z } \\
(\%)\end{array}$ & $\begin{array}{c}\text { AM } \\
(\%)\end{array}$ & $\begin{array}{c}\text { RO } \\
(\%)\end{array}$ & $\begin{array}{c}\text { ST } \\
(\%)\end{array}$ & $\begin{array}{c}\text { CPX } \\
(\%)\end{array}$ & $\begin{array}{c}\text { SEP } \\
(\%)\end{array}$ & $\begin{array}{c}\text { E } \\
(\%)\end{array}$ \\
\hline 65 & 75.0 & 75.0 & 25.0 & 25.0 & 25.0 & 75.0 & 50.0 & 75.0 & 25.0 & 50.0 \\
\hline 66 & 75.0 & 50.0 & 25.0 & 50.0 & 25.0 & 50.0 & 50.0 & 50.0 & 25.0 & 25.0 \\
\hline 67 & 50.0 & 50.0 & 25.0 & 25.0 & 25.0 & 25.0 & 50.0 & 25.0 & 50.0 & 25.0 \\
\hline 68 & 50.0 & 50.0 & 25.0 & 50.0 & 25.0 & 50.0 & 25.0 & 50.0 & 25.0 & 25.0 \\
\hline 69 & 75.0 & 75.0 & 25.0 & 75.0 & 50.0 & 75.0 & 75.0 & 75.0 & 50.0 & 50.0 \\
\hline Total 5 & $\mathbf{3 2 5 . 0}$ & $\mathbf{3 0 0 . 0}$ & $\mathbf{1 2 5 . 0}$ & $\mathbf{2 2 5 . 0}$ & $\mathbf{1 5 0 . 0}$ & $\mathbf{2 7 5 . 0}$ & $\mathbf{2 5 0 . 0}$ & $\mathbf{2 7 5 . 0}$ & $\mathbf{1 7 5 . 0}$ & $\mathbf{1 7 5 . 0}$ \\
\hline Average & $\mathbf{6 5 . 0 \%}$ & $\mathbf{6 0 . 0} \%$ & $\mathbf{2 5 . 0} \%$ & $\mathbf{4 5 . 0 \%}$ & $\mathbf{3 0 . 0} \%$ & $\mathbf{5 5 . 0} \%$ & $\mathbf{5 0 . 0} \%$ & $\mathbf{5 5 . 0} \%$ & $\mathbf{3 5 . 0} \%$ & $\mathbf{3 5 . 0} \%$ \\
\hline
\end{tabular}

$\mathrm{PEF}=$ Pefloxacine, $\mathrm{GN}=$ Gentamycin, APX=Ampiclox, $\mathrm{Z}=$ Zinnat, AM=Ampicillin, $\mathrm{RO}=$ Rocephin, $\mathrm{ST}=$ Streptomycin, $\mathrm{CPX}=$ Ciprofloxacin, $\mathrm{SEP}=$ Septrin, $\mathrm{E}=$ Erythromycin

Table 6. Unpaired t-test statistical Analysis of Susceptibility Differences in response to Antibiotics by Staph. aureus $(\mathrm{n}=24)$ and Pseudo. aeruginosa $(\mathrm{n}=11)$

\begin{tabular}{|c|c|c|c|}
\hline Antibiotics & $\begin{array}{c}\text { Staph. aureus } \\
(\bar{X} \pm S . E)\end{array}$ & $\begin{array}{c}\text { Pseudo. aeruginosa } \\
(\bar{X} \pm S . E)\end{array}$ & P-value \\
\hline OFX & $1.33 \pm 0.67$ & $1.89 \pm 0.14$ & $\mathrm{P}>0.05(0.580)$ \\
\hline PEF & $2.06 \pm 0.13$ & $2.00 \pm 0.12$ & $\mathrm{P}>0.05(0.776)$ \\
\hline GN & $2.04 \pm 0.07$ & $1.67 \pm 0.32$ & $\mathrm{P}>0.05(0.128)$ \\
\hline AM & $1.26 \pm 0.15$ & $1.50 \pm 0.20$ & $\mathrm{P}>0.05(0.362)$ \\
\hline Z & $1.96 \pm 0.10$ & $2.00 \pm 0.08$ & $\mathrm{P}>0.05(0.802)$ \\
\hline$*$ ST & $\mathbf{1 . 8 9} \pm \mathbf{0 . 0 6}$ & $\mathbf{1 . 0 6} \pm \mathbf{0 . 3 5}$ & $\mathbf{P}<\mathbf{0 . 0 1}(\mathbf{0 . 0 0 2})$ \\
\hline RO & $1.39 \pm 0.15$ & $1.11 \pm 0.29$ & $\mathrm{P}>0.05(0.350)$ \\
\hline CPX & $1.33 \pm 0.67$ & $1.06 \pm 0.27$ & $\mathrm{P}>0.05(0.790)$ \\
\hline SP & $1.33 \pm 0.67$ & $1.44 \pm 0.19$ & $\mathrm{P}>0.05(0.914)$ \\
\hline$*$ AU & $\mathbf{1 . 8 3} \pm \mathbf{0 . 1 7}$ & $\mathbf{0 . 7 2} \pm \mathbf{0 . 2 9}$ & $\mathbf{P}<\mathbf{0 . 0 1}(\mathbf{0 . 0 0 1 4})$ \\
\hline
\end{tabular}

$25.0 \%=$ mildly sensitive

$50.0 \%=$ moderately sensitive

75.0\% above $=$ markedly sensitive

$\mathrm{R}=$ Resistant, $\mathrm{ST}=$ streptomycin, $\mathrm{RO}=$ Rocephine, $\mathrm{CPX}=$ Ciprofloxacin, $\mathrm{SEP}=$ Septrin, $\mathrm{E}=$ Erythromycin, $\mathrm{CHL}$ = Chloramphenicol, GN = Gntamycin, $\mathrm{APX}=$ Ampiclox, $\mathrm{AM}=$ Ampicillin, $\mathrm{SP}=$ Sperfloxacin, $\mathrm{AU}=\mathrm{Augmentin}$, $\mathrm{Z}=$ Zinnat, $\mathrm{OFX}=$ Ofloxacin (Tarivid), $\mathrm{PEF}=$ pefloxacine, $\mathrm{AMX}=$ Amoxicillin Significant Results 